\title{
inorganics
}

ISSN 2304-6740

www.mdpi.com/journal/inorganics

Review

\section{Gilded Hope for Medicine}

\section{Mohamed El Naggar ${ }^{1}$, Ihsan Shehadi ${ }^{1}$, Hanan E. Abdou ${ }^{2}$ and Ahmed A. Mohamed ${ }^{1,3, *}$}

1 Department of Chemistry, University of Sharjah, Sharjah 27272, United Arab Emirates;

E-Mails: melnagrr@sharjah.ac.ae (M.E.N.); ishehadi@sharjah.ac.ae (I.S.)

2 Department of Chemistry, Blinn College, Bryan, TX 77805, USA; E-Mail: hanan.abdou@blinn.edu

3 Department of Chemistry, Delaware State University, 1200 N. DuPont Highway, Dover, DE, USA

* Author to whom correspondence should be addressed; E-Mail: ah.mohamed@sharjah.ac.ae; Tel.: +1-979-485-0684.

Academic Editor: Antonio Laguna

Received: 30 January 2015 / Accepted: 15 April 2015 / Published: 15 May 2015

\begin{abstract}
Gold is emerging as a potential therapeutic agent in the treatment of arthritis, cancer and AIDS. The therapeutic mechanism of arthritic gold drugs and their modification in the presence of stomach hydrochloric acid, in the joints, and in the presence of mild and strong oxidizing agents is a matter of debate. It is believed that gold affects the entire immune response and reduces its potency and limits its oxidizing nature. DNA apparently is not the main target of gold in cancer treatment. Rheumatoid arthritis, cancer, heart diseases and recently AIDS have all been targeted with gold nanoparticles therapy. The era of gold nanoparticles started with cancer imaging and treatment studies. Gold nanoparticles have emerged as smart drug vehicles.
\end{abstract}

Keywords: gold drugs; gold nanoparticles; rheumatoid arthritis; chrysotherapy; cancer; HIV 


\section{Introduction}

While ancient civilizations may not have known exactly what made gold so valuable, there is no challenge to its exponential influence in our life. The medicinal characters of gold have been realized since the ancient history of Egypt. Gold in the form of liquid was used by the Egyptians to restore youth and ward off diseases and evil spirits [1-3]. In the eighth century CE, Jabir ibn Hayyan produced the gold acid by dissolving gold in aqua regia [4]. Robert Boyle noted that gold could be precipitated into a crystalline salt after dissolving in aqua regia [5]. Gold was dissolved in aqua regia, diluted with water, and then precipitated with potassium hydroxide solution [4]. Colloidal gold solution in modern times [610] was prepared by the great alchemist Paracelsus and called his purple solution potable gold.

Gold syrup was used in the $17^{\text {th }}$ century for the treatment of ailments caused by a decrease in the vital spirits [11]. In the $19^{\text {th }}$ century, gold chloride mixture with sodium chloride was used as a drug for the treatment of syphilis [6], which was later used in many of the European pharmacopoeias [7]. In 1857, Faraday prepared colloidal gold [8]. Modern medicine of gold began with the bacteriostatic role of $\mathrm{K}\left[\mathrm{Au}(\mathrm{CN})_{2}\right]$ towards the tubercle bacillus [12] which in the 1920 s was used for tuberculosis therapy.

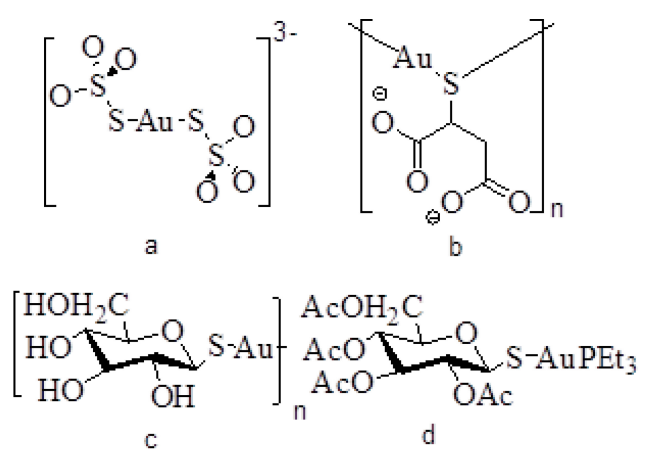

Figure 1. Representation of some of the antirheumatoid arthritis gold(I) drugs. (a) sanocrysin, (b) myocrysine, (c) solganol, and (d) auranofin.

Chrysotherapy is the modern term used for the role of gold in medicine. The early gold compounds (drugs) used were the water soluble, injectable gold(I) thiolates such as aurothiosulfate (sanocrysin), aurothiomalate (myocrysine) and aurothioglucose (solganol). In 1976, triethylphosphine gold(I) tetraacetylthioglucose (auranofin) was approved by the FDA as an orally active drug for the treatment of rheumatoid arthritis (RA) (Figure 1) [13,14].

\section{Rheumatoid Arthritis}

Rheumatoid arthritis is accompanied by erosion of the joints, disfigurements, immobility, and pain [15]. Highly toxic reactive oxygen species (ROS) such as superoxide $\left(\mathrm{O}_{2}^{-}\right)$(Equations 1-6) [16] are produced by oxidative burst. Superoxide is converted to hydrogen peroxide $\left(\mathrm{H}_{2} \mathrm{O}_{2}\right)$ when catalyzed by superoxide dismutase (SOD, a class of enzymes that catalyzes the dismutation of superoxide into hydrogen peroxide and oxygen). In the presence of transition metal ions such as $\mathrm{Fe}(\mathrm{II})$, hydrogen peroxide and superoxide are converted to highly reactive hydroxyl radicals $(\mathrm{OH} \cdot)$. Additionally, the enzyme myeloperoxidase catalyzes the oxidation of chloride to hypochlorite $\left(\mathrm{OCl}^{-}\right)$by hydrogen 
peroxide. Singlet oxygen $\left({ }^{1} \mathrm{O}_{2}\right)$ is produced by the reaction of hydrogen peroxide with hypochlorite. Finally, nitric oxide reacts with superoxide to produce peroxynitrite anion $\left(\mathrm{ONOO}^{-}\right)$[16].

$$
\begin{gathered}
\text { NADPH oxidase: } 2 \mathrm{O}_{2}+\mathrm{NADPH} \rightarrow 2 \mathrm{O}_{2}^{-}+\mathrm{NADPH}^{+}+\mathrm{H}^{+} \\
\text {Superoxide dismutase: } 2 \mathrm{O}_{2}^{-}+2 \mathrm{H}^{+} \rightarrow \mathrm{O}_{2}+\mathrm{H}_{2} \mathrm{O}_{2} \\
\text { Myeloperoxidase: } \mathrm{Cl}^{-}+\mathrm{H}_{2} \mathrm{O}_{2} \rightarrow \mathrm{OCl}^{-}+\mathrm{H}_{2} \mathrm{O} \\
\mathrm{H}_{2} \mathrm{O}_{2}+\mathrm{Fe}^{2+} \rightarrow \mathrm{OH}^{-}+\mathrm{OH} \cdot \mathrm{Fe}^{3+} \\
\mathrm{H}_{2} \mathrm{O}_{2}+\mathrm{OCl}^{-} \rightarrow{ }^{1} \mathrm{O}_{2}+\mathrm{H}_{2} \mathrm{O}+\mathrm{Cl}^{-} \\
\mathrm{NO}+\mathrm{O}_{2}^{-} \rightarrow \mathrm{ONOO}^{-}
\end{gathered}
$$

\section{Gold Oxidation States}

Gold exists in a number of oxidation states: -I, 0, I, II, III, IV and V; however, only gold 0, I and III are known to be stable. Gold(I) is thermodynamically more stable than gold(III) [17]. Many gold(III) complexes are strong oxidizing agents and generally toxic in biological systems (Equations 7-9). Gold oxidation state III is accessible under physiologically oxidizing conditions. Thus, a redox cycle is initiated by the reduction of gold(III) to gold(I) by biological reductants [18].

$$
\begin{array}{cc}
\mathrm{Au}(\mathrm{I})+1 \mathrm{e} \rightarrow \mathrm{Au}(0) & E_{0}=+1.68 \mathrm{~V} \\
\mathrm{Au}(\mathrm{III})+3 \mathrm{e} \rightarrow \mathrm{Au}(0) & E_{0}=+1.42 \mathrm{~V} \\
3 \mathrm{Au}(\mathrm{I}) \rightarrow 2 \mathrm{Au}(0)+\mathrm{Au}(\mathrm{III}) & E_{0}=+0.47 \mathrm{~V}
\end{array}
$$

The chemistry of gold differs greatly from other elements in the same group such as copper and silver. Some differences can be ascribed to the relativistic effects that perturb the $6 \mathrm{~s}$ orbital in gold, but are not significant for the outer valence orbitals of copper and silver [19]. Gold(I) is a soft metal ion and therefore has a preference for sulfur and carbon donor ligands [20].

\section{Structure of Arthritic Gold Drugs}

Table 1. Gold drugs used in chrysotherapy.

\begin{tabular}{ccc}
\hline Drug name & Trade name & Formula \\
\hline Gold thiosulfate & Sanochrysin & $\mathrm{Na}_{3}\left[\mathrm{Au}\left(\mathrm{S}_{2} \mathrm{O}_{3}\right)_{2}\right]$ \\
& Myochrysine & $\mathrm{Na}_{2}[\mathrm{AuTm}]$ \\
Gold thiomalate & Solganol & {$[\mathrm{AuTG}]_{n}$} \\
Gold thioglucose & Auranofin & $\mathrm{Et}_{3} \mathrm{PAuTATG}$ \\
\hline
\end{tabular}


Sodium aurothiomalate (myochrysine) is a hexameric ring polymeric drug with thiolate sulfur centers bridging linear gold(I) ions (Table 1) [21]. Extended X-ray absorption fine structure (EXAFS) of solganol shows a 1:1 polymeric complex with bridging thiolate sulfur centers and gold-gold contacts of less than $3.6 \AA[22]$. Myochrysine analogue $\left[\mathrm{CsNa}_{2} \mathrm{HAu}_{2}(\mathrm{Tm})_{2}\right]_{n}$ was crystallized using hanging drop vapor diffusion technique (Figure 2). X-ray crystal structure of a side view of the two intertwined helices shows that the gold-sulfur chain is linear at gold and bent at sulfur. The polymeric structure shows the closest inter-strand gold-gold distance of 3.227(5) $\AA$ [23]. In sanocrysin drug, $\mathrm{Na}_{3}\left[\mathrm{Au}\left(\mathrm{S}_{2} \mathrm{O}_{3}\right)_{2}\right] 2 \mathrm{H}_{2} \mathrm{O}$, the gold center is bonded to the sulfur atoms from the two thiosulfate moieties in a nearly linear arrangement. The anions are relatively close, giving a short gold-gold distance of $3.302 \AA$ [24].

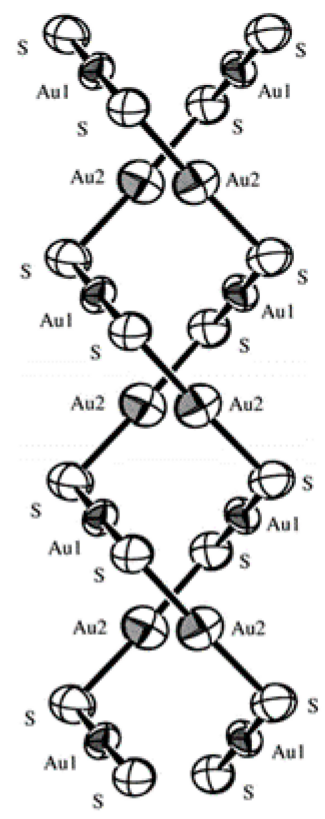

Figure 2. Side view of the gold-sulfur double helix in myocrysine analogue. Adapted with permission from ref. [23]. Copyright 1998 American Chemical Society.

Auranofin X-ray structure shows a nearly linear arrangement of phosphine-gold-sulfur, P-Au-S angle of $173.6^{\circ}$ [25]. The glucopyranose ring exists in chair conformation with all groups oriented equatorially. The $\beta$-configuration of the anomeric $\mathrm{C}$-S bond on the basis of synthesis and optical rotation was confirmed.

\section{Mechanism of Action and Fate of Gold Drugs}

\subsection{Fate of Auranofin in Stomach Hydrochloric Acid}

The effect of aqueous $\mathrm{HCl}$ on auranofin was studied at stomach $\mathrm{pH}$ 1.0. The cationic dinuclear gold(I) complex $\left[\mathrm{RS}\left(\mathrm{Et}_{3} \mathrm{PAu}\right)_{2}\right]^{+}(\mathrm{RS}=2,3,4,6$-tetra-acetyl-1-thio-beta-D-glucopyranosato) was proposed as one of the products (Equation 10). The mechanism of auranofin reaction with $\mathrm{HCl}$ occurs by the formation of a three-coordinate gold complex through an associative step which involves the coordination of chloride [26].

$$
2 \text { auranofin }+\mathrm{HCl} \rightleftharpoons\left[\mathrm{RS}\left(\mathrm{Et}_{3} \mathrm{PAu}\right)_{2}\right] \mathrm{Cl}+\mathrm{RSH}
$$




\subsection{Interaction of Gold Drugs with Proteins "Shuttle Thiol Mechanism"}

The major binding site for gold drugs in plasma is the cysteine-34 free thiol of human serum albumin [27]. The thiolate of the gold drug being exchanged with the cysteine-34 of albumin induces a structural transition from "buried" to "exposed" (Figure 3). This is consistent with the rapid elimination of the thiolate than gold(I) from the bloodstream. Gold(I) is likely to undergo a thiol exchange reaction and penetrate the cell by the shuttle thiol mechanism [28]. The first order reaction rate of albumin and zero with respect to auranofin indicates that auranofin stays intact for a few seconds before it exchanges in the blood.

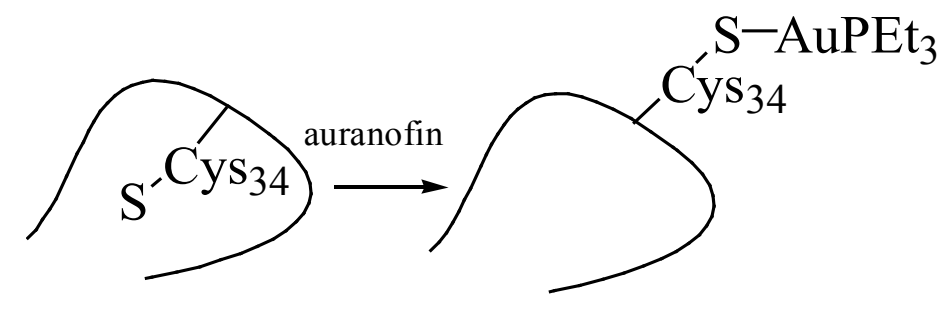

Figure 3. Interaction of auranofin with cys 34 of albumin.

\subsection{Mild Oxidation of Auranofin}

A crucial aspect in the oxidation potential of arthritic drugs is the redox power of the cell environment and the in vivo conditions required to initiate the electron-transfer cycle. Administered arthritic gold thiolate drugs presumably dissociate in the body under oxidative conditions and undergo different metabolic processes.

Electrochemical oxidation of auranofin and its model complexes in dichloromethane studied by the Bruces shows two broad irreversible oxidation peaks [29]. It is likely that gold(I) is oxidized to gold(III) followed by a chemical step. Chemical oxidation of auranofin by the mild oxidizing agent ferrocenium cation, $[\mathrm{Fc}]^{+}$suggests that the oxidation in vivo may occur at potentials that are biologically accessible under normal cellular conditions [30,31].

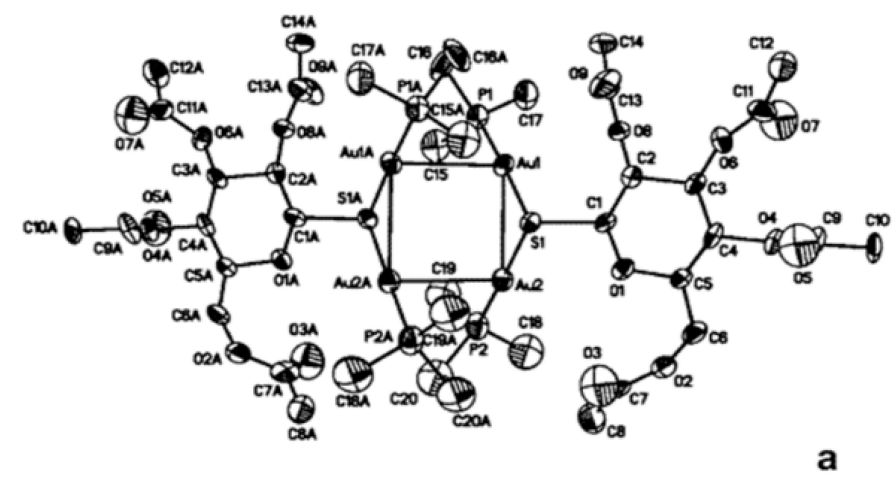

Figure 4. Cont. 


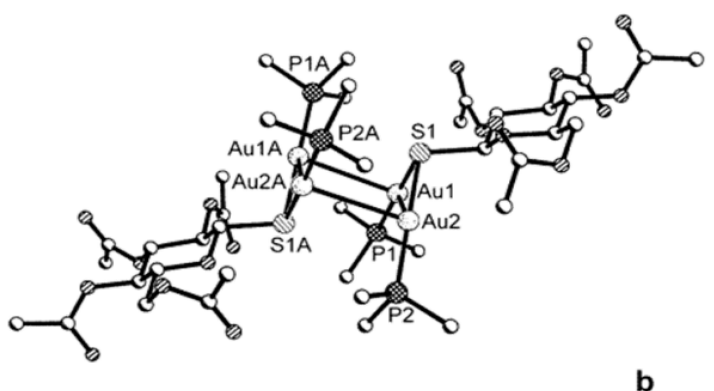

Figure 4. Tetranuclear cationic gold(I) complex $\left[\left(\mathrm{Me}_{3} \mathrm{PAu}\right)_{2}(\mathrm{SR})\right]_{2}{ }^{2+}$ formed by chemical oxidation of auranofin analogue using ferrocenium cation. (a) Thermal ellipsoid representation (50\%) looking down on the gold square and (b) ball-and-stick representation shown as a side view. Adapted with permission from ref. [31]. Copyright 2003 American Chemical Society.

The oxidation potential of auranofin supports the HOMO as mainly sulfur in character [32] which results in gold-sulfur bond cleavage and the formation of a thiyl radical. The thiyl radicals rapidly dimerize to a disulfide (Equation 11). The gold(I) phosphine cation $\left[\mathrm{R}_{3} \mathrm{PAu}\right]^{+}$reacts with another starting molecule to form a dinuclear gold(I) complex (Figure 4) [33].

$$
4 \text { Auranofin }+2[\mathrm{Fc}] \mathrm{PF}_{6} \rightarrow \mathrm{RSSR}+2 \mathrm{Fc}+\left[\left(\mathrm{Et}_{3} \mathrm{PAu}\right)_{2}(\mathrm{SR})\right]_{2}\left(\mathrm{PF}_{6}\right)_{2}
$$

\subsection{Reduction of Gold(I) to Gold(0) in Joints "Aurosomes"}

The electrochemical reduction of auranofin in ethanol/water solvent mixture occurs at $-0.50 \mathrm{~V} v s$. $\mathrm{SCE}(-0.26 \mathrm{~V} v s$. NHE) above $\mathrm{pH}$ 9.0. The number of electrons calculated in auranofin reduction is one, which corresponds to gold(I) to elemental gold reduction [34].

Gold(0) is formed in vivo from gold(I) thiolate drugs according to electron microscopy studies [35]. Electron-dense deposits of gold(0) were located in the macrophage-like cells of the synovial tissues in patients infected with rheumatoid arthritis. These deposits are contained within lysosomes ('aurosomes') (Figure 5) [35,36]. To test the hypothesis that gold(0) might be pharmacologically active, a colloidal gold was administered subcutaneously and it proved to be almost 1000 times more potent than myocrysine [37].

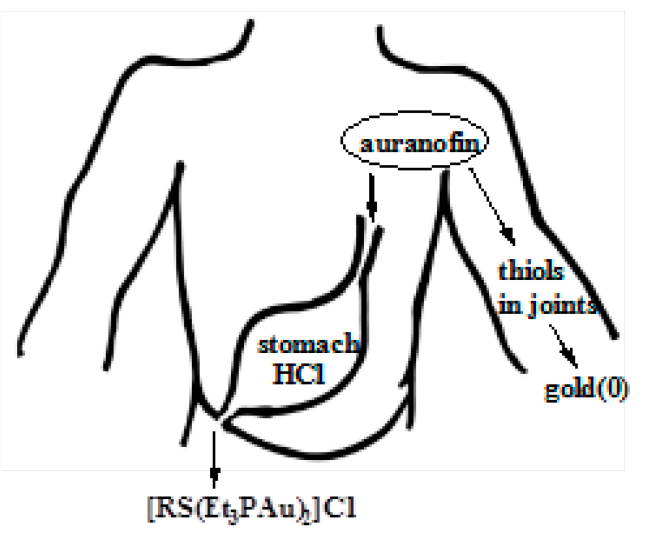

Figure 5. Fate of auranofin in stomach and joints. 


\subsection{Strong Oxidation of Gold Drugs}

Gold(I) drugs are susceptible to oxidation to gold(III) by the strong oxidizing agent myeloperoxidase (MPO) generated hypochlorite $\left(\mathrm{OCl}^{-}\right)$(Scheme 1). Strong oxidizing agents activate the three redox active centers in gold drugs; sulfur to sulfonate, phosphine to phosphine oxide and gold(I) to gold(III) [38-40]. This results in the formation of three metabolites with various excretion rates. Gold(III) appears only after the initial oxidation of sulfur and phosphine. Gold(I) is likely to be oxidized to gold(III) which is affected by the concentration of MPO, $\mathrm{H}_{2} \mathrm{O}_{2}$, and gold(I).

\subsection{Activation of Gold(I) Drugs by Forming Gold(I) Cyanide Metabolite}

The stability constant for gold(I) cyanide $\left[\mathrm{Au}(\mathrm{CN})_{2}\right]^{-}$is $10^{39}$ and that for gold(III) cyanide $\left[\mathrm{Au}(\mathrm{CN})_{4}\right]^{-}$ is reported as $\sim 10^{56}[1]$. The cyanoaurate complexes are stable to low $\mathrm{pH}$ values. The high stability of the gold(I) cyanide complexes reflects an extremely small concentration of gold in solution.

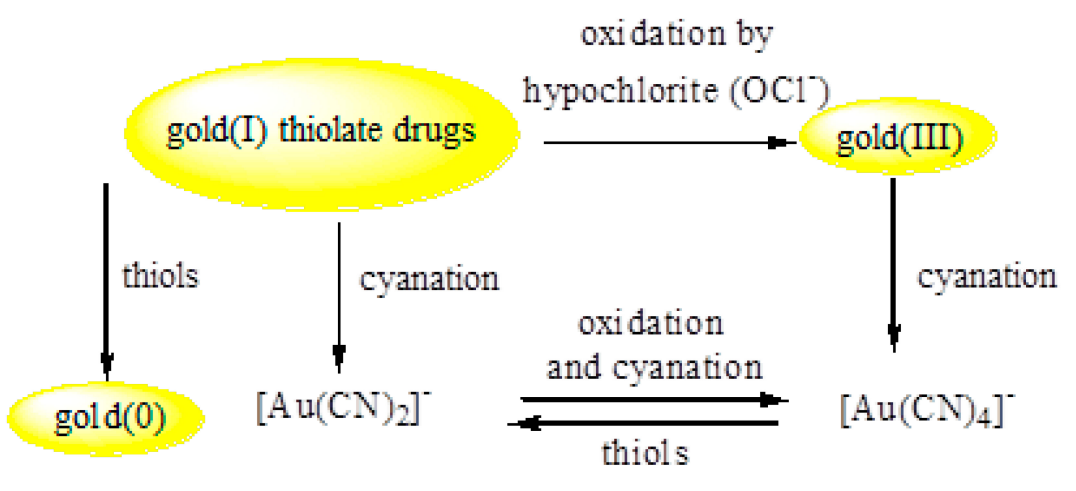

Scheme 1. Redox cycle of gold(I) thiolate drugs.

$$
[\mathrm{AuSR}]_{n}+2 \mathrm{CN}^{-} \rightarrow\left[\mathrm{Au}(\mathrm{CN})_{2}\right]^{-}+\mathrm{RS}^{-}
$$

Gold(I) drugs react with cyanide present in small concentrations in blood, either endogenous or from cigarette smoking (Scheme 1). Cyanide activates aurothiomalate drug and related polymeric complexes through the conversion to the very stable aurocyanide complex $\left[\mathrm{Au}(\mathrm{CN})_{2}\right]^{-}[41-43]$. Traces of $\left[\mathrm{Au}(\mathrm{CN})_{2}\right]^{-}$have been identified as a common metabolite of gold drugs (Equation 12).

Oxidation of $\left[\mathrm{Au}(\mathrm{CN})_{2}\right]^{-}$by myeloperoxidase in PMN leukocytes and further cyanation of the generated gold(III) to $\left[\mathrm{Au}(\mathrm{CN})_{4}\right]^{-}$is postulated as a possible pathway of an immunologically generated gold(I)/gold(III) redox cycle in vivo (Scheme 1). The reduction of $\left[\mathrm{Au}(\mathrm{CN})_{4}\right]^{-}$by thiols to $\left[\mathrm{Au}(\mathrm{CN})_{2}\right]^{-}$ probably proceeds through two intermediates [44-47].

\subsection{Smoking and the Clinical Response to Gold Drugs}

Smokers treated with gold drugs are reported to have higher concentrations of gold in their red blood cells compared with nonsmokers [48,49] probably due to the formation of the very stable aurocyanide complex $\left[\mathrm{Au}(\mathrm{CN})_{2}\right]^{-}$. $\mathrm{HCN}$ is metabolized to $\mathrm{SCN}^{-}$in the liver of smokers which supports the finding that smokers have higher plasma concentrations of thiocyanate than nonsmokers. Thus, greater synthesis of aurocyanide complex $\left[\mathrm{Au}(\mathrm{CN})_{2}\right]^{-}$is anticipated in smokers. 


\subsection{Toxicity of Gold Rheumatoid Drugs}

Rheumatoid arthritis drugs are administered to alleviate the symptoms and to slow the disease progression. Skin rash and discoloration, oral ulcers and other side effects have been reported in patients treated with gold drugs. The negative effects of gold drugs can persist even after halting gold treatment [50-52].

\subsection{General Comments on the Mechanism of Action}

Redox perturbation plays a major role in many diseases. Gold drugs utilize redox cycling in their action in the body. Understanding the activation step, i.e., disulfide activation, will ultimately support broader medicinal applications of the various types of therapeutic agents. Apart from the general belief that metal-based drugs function in the body by the e-shuttle mechanism, the "activation by redox" has become a more conceivable route in the therapeutic action.

Fackler demonstrated that mononuclear and dinuclear gold(I) complexes are capable of activating disulfides. The reaction of the disulfide $\mathrm{PhCH}_{2} \mathrm{SSCH}_{2} \mathrm{Ph}$ with $\left[\mathrm{Au}\left(\mathrm{PPh}_{3}\right)\right] \mathrm{NO}_{3}$ formed a cationic gold cluster $\left[\mathrm{Au}_{2}\left(\mathrm{R}_{3} \mathrm{P}\right)_{2}(\mu-\mathrm{SR})\right]^{+}[53]$. The role that gold cation $\left[\mathrm{Me}_{3} \mathrm{PAu}\right]^{+}$plays in promoting disulfide bond cleavage was assessed by using tandem mass spectrometry. The $\left[\mathrm{Me}_{3} \mathrm{PAu}\right]^{+}$cation promoted disulfide bond cleavage of cystine. The most abundant S-S and C-S bond cleavage reactions were observed [54]. Theoretical studies on disulfide models suggest electrophilic and oxidative-addition mechanisms which are initiated by coordination of the gold species to the disulfide bond [55].

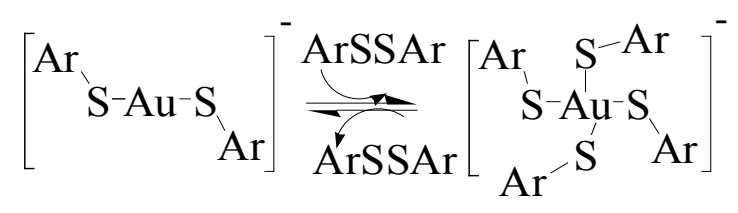

Figure 6. Reversible addition-elimination of disulfides to a mononuclear gold thiolate complex, $\mathrm{Ar}=\mathrm{C}_{6} \mathrm{~F}_{5}$.

Fluorinated disulfides activate gold thiolate complexes by oxidative addition/reductive elimination processes under thermal and photochemical pathways (Figure 6) [56]. Gold(III) intermediate is likely to form in gold thiolate drugs via similar processes.

\section{Promising Gold Therapeutic Anticancer Properties}

The interest in gold(III) as anticancer agent is a result of the current significance of the anticancer cisplatin, cis-diamminedichloroplatinum(II), [ $\left.\mathrm{PtCl}_{2}\left(\mathrm{NH}_{3}\right)_{2}\right]$ [57]. Although cisplatin has been used for a long time for the treatment of different types of cancer there are several limitations and drawbacks. Gold(III) compounds provided alternative class of drugs. Gold(III) compounds, isoelectronic $\left(\mathrm{d}^{8}\right)$ with platinum(II), form four-coordinate with a square planar geometry. Cisplatin complexes target DNA in their mechanism of action in cancer treatment, however gold cytotoxicity may originate from their ability to modify mitochondrial function $[58,59]$. 


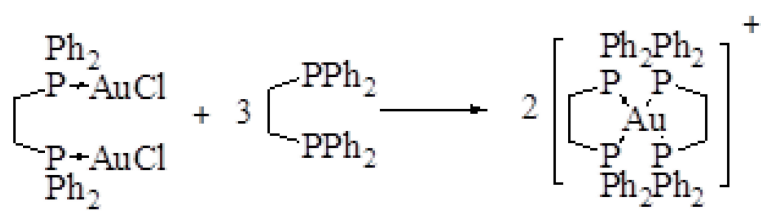

The lipophilic phosphine gold compounds can readily enter the cells while the more hydrophilic oligomeric thiolates do not accumulate in cells, and are inactive in cancer treatment [60,61]. Disphosphine gold(I) compound $\left[(\mathrm{AuCl})_{2}(\mathrm{dppe})\right]$, dppe = bis(diphenyl)phosphine, has shown activity against the M5076 reticulum cell sarcoma, subcutaneous mammary adenocarcinoma, and P388 leukemia [62]. In the presence of more dppe ligands, $\left[(\mathrm{AuCl})_{2}(\mathrm{dppe})\right]$ undergoes ring closure to form the tetrahedral compound cation $\left[\mathrm{Au}(\mathrm{dppe})_{2}\right]^{+}$, which is suggested to be the active species (Equation 13). An important advantage of gold diphosphine compounds in cancer therapy is the ability to change the substituents on the phosphorous centers, and hence modify the lipophilicity or hydrophilicity [63]. Gold(I) phosphine compounds have shown antitumor activity, especially among cisplatin-resistant cell lines, but their clinical trials were halted due to acute toxicity in heart, liver, and lungs $[58,59,64]$.

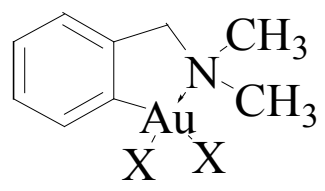

Figure 7. Structure of $\left[\mathrm{Au}(\mathrm{damp}) \mathrm{X}_{2}\right]$, damp $=$ 2-dimethylaminomethylphenyl, $\mathrm{X}=\mathrm{Cl}$ or acetate.

Proteins may be the main target by another investigated class of gold(III) compounds [Au(damp) $\mathrm{X}_{2}$ ], $\mathrm{X}$ $=$ chloride or acetate (Figure 7) [65]. Dithiocarbamates $\left[\mathrm{AuX}_{2}\left(\mathrm{~S}_{2} \mathrm{CNR}_{2}\right)\right], \mathrm{X}=\mathrm{Cl}, \mathrm{Br}$, have shown four orders cytotoxicity of magnitude than cisplatin (Figure 8) [66-69]. Gold(I) N-heterocyclic carbenes (NHC), $\left[\mathrm{Au}(\mathrm{NHC})_{2}\right]^{+}$, are similar to phosphine ligands in terms of their metal coordination chemistry [70] and have shown antimitochondrial activity [71]. An advantage of the NHC class is the ability to modify their hydrophilic and lipophilic properties by varying the substituents [72].

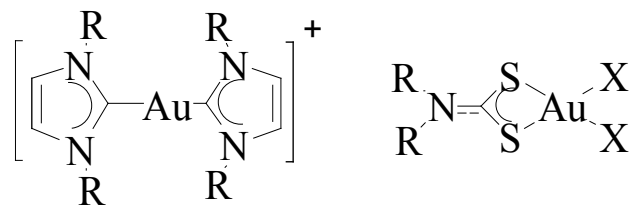

Figure 8. Structure of gold(I) carbene and gold(III) dithiocarbamate.

The rising use of gold complexes in cancer treatment has provided several complexes for trials but there is no mechanism of action yet on how gold enters the cell and the fate of the ligands associated with gold. Unlike arthritic drugs, gold cancer drugs have not been approved for marketing. The research in this area ascertained the fact that gold drugs are incorporated in the body and in a different pathway than platinum drugs. 


\section{Anti-HIV Activity of Gold}

Water soluble gold-thiolate drugs solganol and myocrysine have shown promising results as anti HIV by ligand exchange mechanism of the reactive species bis(thiolato) gold(I) and acidic thiol groups exposed on viral surface proteins as well as by inhibition of reverse transcriptase in cell-free assays $[73,74]$. Auranofin has shown an increase in the CD4+ count [75]. Gold cyanide was also reported to have anti-HIV activity through inhibition of reverse transcriptase [76]. Aurocyanide probably hinders HIV proliferation [77]. Gold(I) phosphine complexes were tested for potential inhibition of HIV enzymes supported by the fact that the presence of this group can result in lipophilicity [78].

\section{Current Status of Gold Nanoparticles Therapy}

Gold nanoparticles area of research has been the hope for medicine in biomedical engineering [79]. Rheumatoid arthritis, cancer, heart diseases and recently AIDS have all been targeted with gold nanoparticles therapy. The era of gold nanoparticles started with cancer imaging and treatment. In heart diseases, gold nanoparticles have been utilized in the controlled release of nitric oxide from cardiovascular drugs. Gold nanoparticles have shown major contribution in "NO-enhanced medicines." It has been shown that gold nanoparticles can enrich and identify protein S-nitrosylation sites and catalyze nitric oxide generation from blood serum [80]. The process is ascribed to the self-assembly of a thiolate monolayer on the gold nanoparticles surface accompanied by the release of nitric oxide.

Gold nanoparticles have become of immense interest because of their extensive biomedical applications [81,82]. However, biomedical use of gold nanoparticles must be further examined in terms of biocompatibility. Some questions have to be addressed such as: how toxic are gold nanoparticles and at what concentrations can they be injected in the body?

\section{Conclusions}

Investigating gold in the treatment of various diseases supported the developing field of metal-based drugs. The continuous efforts in chrysotherapy greatly included periods of great passion and complete dismissal. The current strong interest in gold research in arthritis, cancer and AIDS anchors the role of gold compounds in medicine. Gold is truly the standout of the metals and the new Gilded Hope for Medicine.

\section{Acknowledgments}

The NSF-SMILE (0928404), NSF-AMP (HRD-0903924), and the Center for Teaching and Learning of Delaware State University are acknowledged for the financial support of this work. Sharjah University is acknowledged for the Competitive Research Projects 2014-2015 grant support.

\section{Author Contributions}

Authors contributed equally to this work. AAM wrote the first draft, MEN worked on the literature, and HEA and IS edited the review. 


\section{Conflicts of Interest}

The authors declare no conflict of interest.

\section{References}

1. Corti, C.; Holliday, R. Gold: Science and Applications; CRC Press: Boca Raton, FL, USA, 2010.

2. Schmidbaur, H. Gold Progress in Chemistry, Biochemistry, and Technology; Wiley: West Sussex, UK, 1999.

3. Mohr, F. Gold Chemistry. Applications and Future Directions in Life Sciences; John Wiley \& Sons: Weinheim, Germany, 2009.

4. Thompson, C.J.S. Alchemy and Alchemists; Dover Publications, Inc.: Mineola, NY, USA, 2002; pp. 18, 61 .

5. Boyle, R. The Sceptical Chymist; Dover Publication, Inc.: Mineola, NY, USA, 2003; p. 31.

6. Goodman, L.S.; Gilman, A. The Pharmacological Basis of Therapeutics, 3rd ed.; The Macmillan Co: New York, NY, USA, 1965; Volume 155, p. 957.

7. Wood, H.C.; Remington, J.P.; Sadtler, S.P. United States Dispensatory, 19th ed.; J.B. Lippincott Co.: Philadelphia, PA, USA, 1907; p. 220.

8. Faraday, M. The Bakerian Lecture: Experimental Relations of Gold (and Other Metals) to Light. Philos. Trans. R. Soc. London 1857, 147, 145-181.

9. Norton, S. A Brief History of Potable Gold. Mol. Interv. 2008, 8, 120-123.

10. Hauser, E.A. Aurum Potabile. J. Chem. Edu. 1952, 29, 456-458.

11. Fricker, S.P. Medical Uses of Gold Compounds: Past, Present and Future. Gold Bull. 1996, 29, 53-60.

12. Koch, R. An Address on Bacteriological Research. Brit. Med. J. 1890, 2, 380-383.

13. Aurothioglucose and Auranofin. In Mosby's GenRx. The Complete Reference for Generic and Brand Drug, 12th ed.; Mosby Year Book: St. Louis, MO, USA, 2002.

14. American College of Rheumatology Subcommittee on Rheumatoid Arthritis Guidelines. Guidelines for the Management of Rheumatoid Arthritis. Arthritis Rheum. 2002, 46, 328-346.

15. Henderson, B.; Edwards, J.; Pettipher, E.R. Mechanisms and Models in Rheumatoid Arthritis. Academic Press: London, UK, 1995.

16. Hitchon, C.A.; El-Gabalawy, H.S. Oxidation in Rheumatoid Arthritis. Arthritis Res Ther. 2004, 6, 265-278.

17. Mohamed, A.A.; Bruce, A.E.; Bruce, M.R.M. Organic Derivatives of Gold and Silver. Patai, S., Rappoport, Z., Eds.; John Wiley \& Sons, Ltd.: Weinheim, Germany, 1999.

18. Shaw, C.F. Gold-Based Therapeutic Agents. Chem. Rev. 1999, 99, 2589.

19. Pyykkö, P. Perspectives: Chemistry: Noblesse Oblige. Science 2000, 290, 64-65.

20. Abdou, H.E.; Mohamed, A.A.; Fackler, J.P., Jr. Gold Chemistry: Highlights and Future Directions; Mohr, F., Ed.; Wiley \& Sons: Weinheim, Germany, 2009, pp. 1-45. 
21. Elder, R.C.; Tepperman, K.G.; Eidsness, M.K.; Heeg, M.J.; Shaw, C.F., III; Schaeffer, N.A. Gold-Based Antiarthritic Drugs and Metabolites. Extended X-ray Adsorption Fine Structure (EXAFS) Spectroscopy and X-ray Absorption Near Edge Spectroscopy (XANES). ACS Symp. Ser. 1983, 209, 385-400.

22. Elder, R.C.; Ludwig, K.; Cooper, J.N.; Eidsness, M.K. EXAFS and WAXS Structure Determination for an Antiarthritic Drug, Sodium Gold(I) Thiomalate. J. Am. Chem. Soc. 1985, 107, 5024-5026.

23. Bau, R. Crystal Structure of the Antiarthritic Drug Gold Thiomalate (Myochrysine): A Double-Helical Geometry in the Solid State. J. Am. Chem. Soc. 1998, 120, 9380-9381.

24. Ruben, H.; Zalkin, A.; Faltens, M.O.; Templeton, D.H. Crystal Structure of Sodium Gold(I) thiosulfate dihydrate, $\mathrm{Na}_{3} \mathrm{Au}\left(\mathrm{S}_{2} \mathrm{O}_{3}\right)_{2} .2 \mathrm{H}_{2} \mathrm{O}$. Inorg. Chem. 1974, 13, 1836.

25. Hill, D.T.; Sutton, B.M. (2,3,4,6-Tetra- $O$-acetyl-1-thio- $\beta$-D-glucopyranosato- $S)$ (triethylphosphine)gold, $\mathrm{C}_{20} \mathrm{H}_{34} \mathrm{AuO}{ }_{9} \mathrm{PS}$. Crystal Structure Commun. 1980, 9, 679-86.

26. Bryan, D.L. B.; Mikuriya, Y.; Hempel, J.C.; Mellinger, D.; Hashim, M.; Pasternack, R.F. Reactions of Auranofin ((1-thio- $\beta$-D-glucopyranose 2,3,4,6-tetraacetato- $S$ )(triethylphosphine) gold(I)) in Aqueous Hydrochloric Acid. Inorg. Chem. 1987, 26, 4180-4185.

27. Christodoulou, J.; Sadler, P.J.; Tucker, A. A New Structural Transition of Serum Albumin Dependent on the State of Cys34. Detection by ${ }^{1} \mathrm{H}-\mathrm{NMR}$ Spectroscopy. Eur. J. Biochem. 1994, 225 , 363-368.

28. Isab, A.A.; Shaw, C.F., III; Locke, J. GC-MS and Oxygen- ${ }^{17}$ NMR Tracer Studies of Triethylphosphine Oxide Formation from Auranofin and Water- ${ }^{17} \mathrm{O}$ in the Presence of Bovine Serum Albumin: an in vitro Model for Auranofin Metabolism. Inorg. Chem. 1988, 27, 3406-3409.

29. Mohamed, A.A.; Abdou, H.E.; Chen, J.; Bruce, A.E.; Bruce, M.R.M. Perspectives in Inorganic and Bioinorganic Gold Sulfur Chemistry. Comments Inorg. Chem. 2002, 23, 321-334.

30. Mohamed, A.A.; Bruce, M.R.M.; Bruce, A.E. Cyclic Voltammetry of Auranofin. Metal Based Drugs 1999, 6, 233-238.

31. Mohamed, A.A.; Chen, J.; Krause Bauer, J.A.; Hill, D.T.; Bruce, A.E.; Bruce, M.R.M. Formation of a Cationic Gold(I) Complex and Disulfide by Oxidation of the Antiarthritic Gold Drug Auranofin. Inorg. Chem. 2003, 42, 2203-2205.

32. Jones, W.B.; Yuan, J.; Narayanaswamy, R.; Young, M.A.; Elder, R.C.; Bruce, A.E.; Bruce, M.R.M. Solid State EXAFS and Luminescence Studies of Neutral, Dinuclear Gold(I) Complexes. Gold(I)Gold(I) Interactions in the Solid State. Inorg. Chem. 1995, 34, 1996-2001.

33. Chen, J.; Jiang, T.; Wei, G.; Mohamed, A.A.; Homrighausen, C.; Bauer, J.; Bruce, A.E.; Bruce, M.R.M. Electrochemical and Chemical Oxidation of Gold(I) Thiolate Phosphine Complexes: Formation of Gold Clusters and Disulfide. J. Am. Chem. Soc. 1999, 121, 9225-9226.

34. Mendez, J.H.; Perez, A.S.; Zamarreno, M.D. Electrochemical Behavior and Polarographic Determination of Auranofin. J. Pharm. Sci. 1989, 78, 589-591.

35. Elder, R.C.; Eidsness, M.K. Synchrotron X-ray Studies of Metal-Based Drugs and Metabolites. Chem. Rev. 1987, 87, 1027-1046.

36. Ghadially, F.N. The Aurosome. J. Rheum. 1979, 6, 45-50.

37. Garrett, I.R.; Whitehouse, M.W.; Vernon-Roberts, B. Ambivalent Properties of Gold Drugs in Adjuvant Induced Polyarthritis in Rats. J. Rheumatol. 1985, 12, 1079-1082. 
38. Goebel, C.; Kubicka-Muranyi, M.; Tonn, T.; Gonzalez, J.; Gleichmann, E. Phagocytes Render Chemicals Immunogenic: Oxidation of Gold(I) to the $\mathrm{T}$ cell-Sensitizing Gold(III) Metabolite Generated by Mononuclear Phagocytes. Arch. Toxicol. 1995, 69, 450-459.

39. Gleichmann, E.; Kubicka-Muranvi, M.; Kind, P.; Goldermann, R.; Goerz, G.; Merk, H.; Rau, R. Insights into the Mechanism of Gold Action Provided by Immunotoxicology: Biooxidation of Gold(I) to Gold(III) Detected by Sensitized T-cells. Rheum. Int. 1991, 11, 219-220.

40. Shaw, C.F. The Mammalian Biochemistry of Gold: an Inorganic Perspective of Chrysotherapy. Inorg Perspect Biol Med. 1979, 2, 287-355.

41. Canumalla, A.J.; Al-Zamil, N.; Phillips, M. Isab, A.A.; Shaw, C.F., III. Redox and Ligand Exchange Reactions of Potential Gold(I) and Gold(III)-Cyanide Metabolites under Biomimetic Conditions. $J$. Inorg. Biochem. 2001, 85, 67-76.

42. Elder, R.C.; Zhao, Z.; Zhang, Y.; Dorsey, J.G.; Hess, E.V.; Tepperman, K. Dicyanogold(I) Is a Common Human Metabolite of Different Gold Drugs. J. Rheumatol. 1993, 20, 268-272.

43. Graham, G.G.; Bales, J.R.; Grootveld, M.C.; Sadler, P.J. ${ }^{1} \mathrm{H},{ }^{13} \mathrm{C}$ NMR, and Electronic Absorption Spectroscopic Studies of the Interaction of Cyanide with Aurothiomalate. J. Inorg. Biochem. 1985, $25,163-173$.

44. Graham, G.G.; Dale, M.M. The Activation of Gold Complexes by Cyanide Produced by Polymorphonuclear Leukocytes. II. Evidence for the Formation and Biological Activity of Aurocyanide. Biochem. Pharmacol. 1990, 39, 1697-1702.

45. Graham, G.G.; Kettle, A. The Activation of Gold Complexes by Cyanide Produced by Polymorphonuclear Leukocytes. III. The Formation of Aurocyanide by Myeloperoxidase. $J$. Biochem. Pharmacol. 1998, 56, 307-312.

46. Shaw, G.F.; Schraa, S.; Gleichmann, E., Grover, Y.P.; Dunemann, L.; Jagarlamudi, A. Redox Chemistry and $\left[\mathrm{Au}(\mathrm{CN})_{2}\right]^{-}$in the Formation of Gold Metabolites. Metal Based Drugs 1994, 1, 351-362.

47. Yangyuoru, P.M.; Webb, J.W.; Shaw, C.F., III. Glutathionato-S-Gold(III) Complexes Formed as Intermediates in the Reduction of Auricyanide by Glutathione. J. Inorg. Biochem. 2008, 102, 584-593.

48. Graham, G.G.; Haavisto, T.M.; Jones, H.M.; Champion, G.D. The Effect of Cyanide on the Uptake of Gold by Red Blood Cells. Biochem. Pharmacol.1984, 33, 1257-1262.

49. Graham, G.G.; Haavisto, T.M.; McNaught, P.J. The Effect of Smoking on the Distribution of Gold in Blood. J. Rheumatol. 1982, 9, 527-531.

50. Kean, W.F.; Kean, I.R. Clinical Pharmacology of Gold. Inflammopharmacology 2008, 16, 107.

51. Tiekink, E.R.T. Gold Compounds in Medicine: Potential Anti-Tumour Agents. Gold Bull. 2003, 36, 117.

52. Ward, J.R.; Williams, N.J.; Egger, J.J.; Reading, J.C.; Boyce, E.; Altz-Smith, M.; Samuelson, C.O.; Willkens, R.F.; Solsky, M.A.; Hayes, S.P.; et al. Comparison of Auranofin, Gold Sodium thiomalate, and Placebo in the Treatment of Rheumatoid Arthritis. A controlled Clinical Trial. Arthritis Rheum. 1983, 26, 1303-1315. 
53. Wang, S.; Fackler, J.P., Jr. Gold Thiolate Complexes with Short Intermolecular Gold-Gold Distances from Reactions of Organic Disulfides with Gold(I) Complexes. Syntheses and Crystal Structures of $\left[\mathrm{AuI}_{2}\left(\mathrm{PPh}_{3}\right)_{2}\left(\mathrm{~m}-\mathrm{SCH}_{2} \mathrm{Ph}\right)\right]\left(\mathrm{NO}_{3}\right)$ and $\mathrm{AuIIICl}_{4}(\mathrm{~m}-\mathrm{SPh})_{2}$. Inorg. Chem. 1990, 29, 4404-4407.

54. Lioe, H.; Duan, M.; O’Hair, R.A.J. Can Metal Ions be Used as Gas-Phase Disulfide Bond Cleavage Reagents? A Survey of Coinage Metal Complexes of Model Peptides Containing an Intermolecular Disulfide Bond. Rapid Commun. Mass Spectrom. 2007, 21, 2727-2733.

55. Gonzales, J.M.; Musaev, D.G.; Morokuma, K. Theoretical Studies of Oxidative Addition of E-E Bonds $(\mathrm{E}=\mathrm{S}$, Se and $\mathrm{Te})$ to $\mathrm{Pd}(0)$ and $\operatorname{Pt}(0)$ Complexes. Organometallics 2005, 24, 4908-4914.

56. Bachman, R.E.; Bodolosky-Bettis, S.A.; Pyle, C.J.; Gray, M.A. Reversible Oxidative Addition and Reductive Elimination of Fluorinated Disulfides at Gold (I) Thiolate Complexes: A new Ligand Exchange Mechanism. J. Am. Chem. Soc. 2008, 130, 14303-14310.

57. Hambley, T.W. Platinum Binding to DNA: Structural Controls and Consequences. J. Chem. Soc. 2001, 19, 2711-2718.

58. Berners-Price, S.J.; Mirabelli, C.K.; Johnson, R.K.; Mattern, M.R.; McCabe, F.L.; Faucette, L.F.; Sung, C.-M.; Mong, S.-M.; Sadler, P.J.; Crooke, S.T. In vivo Antitumor Activity and in vitro Cytotoxic Properties of Bis[1,2-bis(diphenylphosphino)ethane]Gold(I) Chloride. Cancer Res. 1986, 46, 5486-5493.

59. McKeage, M.J.; Berners-Price, S.J.; Galletis, P.; Bowen, R.J.; Brouwer, W.; Ding, L.; Zhuang, L.; Baguley, B. Role of Lipophilicity in Determining Cellular Uptake and Antitumour Activity of Gold Phosphine Complexes. Cancer Chemother. Pharmacol. 2000, 46, 343-350.

60. Tiekink, E.R.T. Gold Derivatives for the Treatment of Cancer. Crit. Rev. Oncol. Hematol. 2002, 42, 225-248.

61. McKeage, M.J.; Maharaj, L.; Berners-Price, S. Mechanisms of Cytotoxicity and Antitumor Activity of Gold(I) Phosphine Complexes: the Possible Role of Mitochondria. J. Coord. Chem. Rev. 2002, 232, 127-135.

62. Berners-Price, S.J.; Sadler, P.J. Phosphines and Metal Phosphine Complexes: Relationship of Chemistry to Anticancer and Other Biological Activity. Struct. Bond. 1988, 70, 27-102.

63. Barnard, P.J.; Berners-Price, S.J. Targeting the Mitochondrial Cell Death Pathway with Gold Compounds. Coord. Chem. Rev. 2007, 251, 1889-1902.

64. Hoke, G.D.; Macia, R.A.; Meunier, P.C.; Bugelski, P.J.; Mirabelli, C.K.; Rush, G.F.; Matthews, W.D. In Vivo and In Vitro Cardiotoxicity of a Gold-Containing Antineoplastic Drug Candidate in the Rabbit. Toxicol. Appl. Pharmacol. 1989, 100, 293-306.

65. Buckley, R.G.; Elsome, A.M.; Fricker, S.P.; Henderson, G.R.; Theobald, B.R.C.; Parish, R.V.; Howe, B.P.; Kelland L.R. Antitumor Properties of Some 2-[(Dimethylamino)methyl] phenylgold(III) Complexes. J. Med. Chem. 1996, 39, 5208-5214.

66. De Vos, D.; Ho, S.Y.; Tiekink, E.R.T. Cytotoxicity Profiles for a Series of Triorganophosphinegold(I) Dithiocarbamates and Triorganophosphinegold(I) Xanthates. Bioinorg. Chem. Appl. 2004, 2, 141-154. 
67. Milacic, V.; Chen, D.; Ronconi, L.; Landis-Piwowar, K.R.; Fregona, D.; Dou, Q.P. A Novel Anticancer Gold(III) Dithiocarbamate Compound Inhibits the Activity of a Purified 20S Proteasome and 26S Proteasome in Human Breast Cancer Cell Cultures and Xenografts. Cancer Res. 2006, 66, 10478-10486.

68. Ronconi, L.; Marzano, C.; Zanello, P.; Corsini, M.; Macca, C.; Trevisan, A.; Fregona, D. Gold(III) Dithiocarbamate Derivatives for the Treatment of Cancer: Solution Chemistry, DNA Binding, and Hemolytic Properties. J. Med. Chem. 2006, 49, 1648-1657.

69. Ronconi, L.; Giovagnini, L.; Marzano, C.; Bettio, F.; Grziani, R.; Pilloni, G.; Fregona, D. Gold Dithiocarbamate Derivatives as Potential Antineoplastic Agents: Design, Spectroscopic Properties, and in Vitro Antitumor Activity. Inorg. Chem. 2005, 44, 1867-1881.

70. Lin, I.J.B.; Vasam, C.S. Review of Gold(I) N-heterocyclic Carbenes. Can. J. Chem. 2005, 83, 812-825.

71. Barnard, P.J.; Bakers, M.V.; Berners-Price, S.J.; Day, D.A. Mitochondrial Permeability Transition Induced by Dinuclear Gold(I)-Carbene Complexes: Potential New Antimitochondrial Antitumour Agents. J. Inorg. Biochem. 2004, 98, 1642-1647.

72. Baker, M.V.; Barnard, P.J.; Berners-Price, S.J.; Brayshaw, S.K.; Hickey, J.L.; Skelton, B.W.; White, A.H. Synthesis and Structural Characterization of Linear Au(I) N-heterocyclic Carbene Complexes: New Analogues of the Au(I) Phosphine Drug Auranofin. J. Organomet. Chem. 2005, 690, 5625-5635.

73. Okada, T.; Patterson, B.K.; Ye, S.; Gurney, M.E. Aurothiolates Inhibit HIV-1 Infectivity by Gold(I) Ligand Exchange with a Component of the Virion Surface. Virology 1993, 192, 631-642.

74. Traber, K.E.; Okamoto, H.; Kurono, C.; Baba, M.; Saliou, C.; Soji, T.; Parker, L.; Okamoto, T. Anti-rheumatic Compound Aurothioglucose Inhibits Tumor Necrosis Factor- $\alpha$-Induced HIV-1 Replication in Latently Infected OM10.1 and Ach2 Cells. Int. Immunol. 1999, 11, 143-150.

75. Shapiro, D.L.; Masci, J.R. Treatment of HIV Associated Psoriatic Arthritis with Oral Gold. J. Rheumatol. 1996, 23, 1818-1820.

76. Tepperman, K.; Zhang, Y.; Roy, P.W.; Floyd, R.; Zhao, Z.; Dorsey, J.G.; Elder, R.C. Transport of the Dicyanogold(I) Anion. Metal-Based Drugs 1994, 1, 433-443.

77. Zhang, Y.; Hess, E.V.; Pryhuber, K.G.; Dorsey, J.G.; Tepperman, K.; Elder, R.C. Gold Binding Sites in Red Blood Cells. Inorg. Chim. Acta 1995, 229, 271-280.

78. Fonteha, P.; Meyer, D. Novel Gold(I) Phosphine Compounds Inhibit HIV-1 Enzymes. Metallomics 2009, 1, 427-433.

79. Schulz, M.J.; Shanov, V.N.; Yun, Y. Nanomedicine Design of Particles, Sensors, Motors, Implants, Robots, and Devices; Artech House, Incorporated: Norwood, MA, USA, 2009.

80. Jia, H.Y.; Liu, Y.; Zhang, X.J.; Han, L.; Du, L.B.; Tian, Q.; Xu, Y.C. Potential Oxidative Stress of Gold Nanoparticles by Induced-NO Releasing in Serum. J. Am. Chem. Soc. 2009, 131, 40-41.

81. Boisselier, E.; Astruc, D. Gold Nanoparticles in Nanomedicine: Preparations, Imaging, Diagnostics, Therapies and Toxicity. Chem. Soc. Rev. 2009, 38, 1759-1782. 
82. Brown, C.L.; Whitehouse, M.W.; Tiekink, E.R. T.; Bushell, G.R. Colloidal Metallic Gold is not Bio-inert. Inflammopharmacology 2008, 16, 133-137.

(C) 2015 by the authors; licensee MDPI, Basel, Switzerland. This article is an open access article distributed under the terms and conditions of the Creative Commons Attribution license (http://creativecommons.org/licenses/by/4.0/). 